\title{
$\mathrm{ZrO}_{2}$ ADDITION IN MOULD POWDERS: EFFECT ON HORIZONTAL HEAT TRANSFER RATE AND SEN EROSION RATE*
}

\author{
Márcia Maria da Silva Monteiro Pereira ${ }^{1}$ \\ Marco Túlio Dias Lima \\ Carlos Berlini Filho ${ }^{3}$ \\ Sebastião Garcia Mendes ${ }^{4}$ \\ Gérson Tolentino Ferreira \\ Detlef Jung ${ }^{6}$ \\ Jeferson Leandro Klug
}

Resumo

Durante o lingotamento contínuo de aço, partículas de $\mathrm{ZrO}_{2}$ adicionadas na escória de molde facilitam a nucleação heterogênea de cristais devido à sua limitada solubilidade. A adição de $\mathrm{ZrO}_{2}$ promove a cristalização da fase cuspidina, o que auxilia na redução da transferência horizontal de calor no molde, amenizando desta forma o problema das trincas longitudinais. Outro benefício da adição de $\mathrm{ZrO}_{2}$ em pós fluxantes é reduzir a taxa de desgaste da válvula submersa (SEN) na interface metal/escória; a erosão da SEN é um problema sério. Através de testes de laboratório e de testes industriais concluiu-se que a adição de $\mathrm{ZrO}_{2}$ em pós fluxantes reduz a taxa de transferência de calor horizontal no molde durante o lingotamento contínuo de aço, considerando os dois tipos de pós fluxantes que foram analisados no presente trabalho. Além disso, observou-se que a adição de $\mathrm{ZrO}_{2}$ reduz a taxa de desgaste da válvula submersa na interface metal/escória.

Palavras-chave: Lingotamento contínuo; Pó fluxante; Erosão da válvula submersa; Trinca longitudinal.

\section{ZrO2 ADDITION IN MOULD POWDERS: EFFECT ON HORIZONTAL HEAT TRANSFER RATE AND SEN EROSION RATE}

\section{Abstract}

During continuous casting of steel, it is accepted that $\mathrm{ZrO}_{2}$ particles in the mould slag act as heterogeneous nucleation sites due to its limited solubility. $\mathrm{ZrO}_{2}$ addition promotes crystallisation of cuspidine and consequently reduces horizontal heat transfer, alleviating in this way problems associated with longitudinal cracking. Another benefit when adding $\mathrm{ZrO}_{2}$ in mould powders is to reduce erosion of SENs at the slag/metal interface; SEN erosion is a serious problem. Through laboratory tests and industrials tests it was concluded that $\mathrm{ZrO}_{2}$ addition in mould powders can reduce horizontal heat transfer rate for the mould during continuous casting of steel, considering two particular mould powders which were studied in the present work. Besides, it was observed that $\mathrm{ZrO}_{2}$ addition reduces erosion of SEN at the slag/metal interface.

Keywords: Continuous casting; Mould powder; SEN erosion; Longitudinal crack.

Eng. Química, Mestra em Eng. Metalúrgica, Supervisora de Laboratório da Stollberg do Brasil, Guaratinguetá, SP, Brasil.

Eng. de Materiais, Eng. de Serviço ao Cliente da Stollberg do Brasil, Guaratinguetá, SP, Brasil. Eng. Metalurgista, Eng. de Processo da Gerdau Ouro Branco, Ouro Branco, MG, Brasil.

Técnico em Metalurgia, Assistente Técnico da Stollberg do Brasil, Guaratinguetá, SP, Brasil.

Gerente de Serviço ao Cliente da Stollberg do Brasil, Guaratinguetá, SP, Brasil.

Eng. de Tecnologia de Processos, Diretor Presidente da Stollberg do Brasil, Guaratinguetá, SP, Brasil.

Eng. Metalúrgico, Doktor-Ingenieur, Prof. Adjunto do Depto. Eng. Metalúrgica e de Materiais, Universidade Federal do Ceará, Fortaleza, CE, Brasil. 


\section{INTRODUCTION}

The continuous casting process is applied to the majority of steel grades by most steel manufacturers. Good understanding and control of phenomena in the mould during production of steel are essential to the success of the process. The slags used in the mould are very important when considering casting results, e.g., the quality of the steel slabs and "sticking severity". The mould slags ultimately have an influence on the capacity of the caster, i.e., how fast it is possible to cast with a good quality and without breakouts caused by sticking [1-4].

When a layer is formed directly on the mould surface either at the beginning of the casting or later on, it will form at first in a glassy state. If there is enough time and the temperature is sufficiently high, devitrification of the layer will take place, resulting in a crystalline phase. The presence of crystals in the liquid layer increases the friction between the mould and strand, leading to a higher incidence of sticker breakouts. On the other hand, a high crystallisation tendency is beneficial in the casting of peritectic steel grades. The formation of a significant crystal fraction in the mould slag film between mould and strand reduces the heat transfer rate and helps alleviate problems associated with longitudinal cracking that arises from the mismatch in the thermal contraction coefficients of $\delta$-ferrite and austenite. This mismatch results in strains on the growing shell, and to minimise these strains, it is important to decrease the heat flux. Anyway, it is clear that in the continuous casting process mould slags crystallisation control is a matter of utmost importance. For example, for high speed thin slab casting, mould powder design concentrates on mild cooling i.e. specific values of basicity and break temperature, promoting the crystallisation of cuspidine $\left(3 \mathrm{CaO} .2 \mathrm{SiO}_{2} . \mathrm{CaF}_{2}\right)[5]$.

During continuous casting process, the presence of crystals in mould slags has a decisive effect on both the lubrication and the heat transfer rate between the mould and the steel strand $[6,7]$.

The crystallisation of cuspidine from mould slag is thought to be the most effective way of exerting horizontal heat transfer control. Although the mechanism of heat transfer control via the crystallisation of cuspidine has not yet been determined, two ideas have been proposed. An idea is that radiation heat flux is decreased by scattering at the boundary between the crystalline and the liquid layers; another idea is that the total heat flux is reduced by the large thermal resistance of the air gap formed as a result of the solidification shrinkage of the solidified slag layer. In any case, the crystallisation of cuspidine from mould slag has a great effect on heat transfer control (for fluorine-bearing mould powders) [8].

Considering $\mathrm{ZrO}_{2}$ addition in mould powders, it is accepted that $\mathrm{ZrO}_{2}$ particles act as heterogeneous nucleation sites due to its limited solubility in molten slag, promoting in this way crystallisation of cuspidine and consequently reducing horizontal heat transfer [9].

Besides horizontal heat transfer control, another benefit when adding $\mathrm{ZrO}_{2}$ in mould powders is to reduce erosion of SENs at the slag/metal interface. The erosion of SENs at the slag/metal interface is a serious problem, and the SEN usually contains an external band of $\mathrm{ZrO} 2 / \mathrm{C}$ ( $\mathrm{Z}$ band) in the interfacial region, since it has much better slag corrosion resistance than $\mathrm{Al} 2 \mathrm{O} 3 / \mathrm{C}$ refractories. A strategy to minimize SEN erosion is to add $\mathrm{ZrO}_{2}$ to the slag, since the solubility of $\mathrm{ZrO}_{2}$ in mould fluxes is thought to be low; in this way the slag is nearly saturated with $\mathrm{ZrO}_{2}$ and thus the driving force for dissolution is dramatically reduced. Much longer SEN lifetimes have 
been claimed with these powders, but it should be noted that $\mathrm{ZrO}_{2}$ additions forces up the break temperature [1].

In the present work, $\mathrm{ZrO}_{2}$ was added to a commercial mould powder which is used at Brazilian steelworks for bloom and beam blank continuous casting. Aim is to evaluate influence of $\mathrm{ZrO}_{2}$ addition on horizontal heat transfer rate in the mould (which is related to defects for the steel) and also on SEN erosion. Laboratory tests and industrial tests comparing the traditional commercial mould powder with the new $\mathrm{ZrO}_{2}$-bearing mould powder are reported in the following.

\section{LABORATORY TESTS}

Compositions for the commercial mould powder ST-SP/BB-04 and for the new $\mathrm{ZrO}_{2^{-}}$ bearing mould powder ST-SP/BB-04Z are shown at Table 1. Laboratory tests and industrial tests for beam blank continuous casting comparing the new $\mathrm{ZrO}_{2}$-bearing mould powder with the ST-SP/BB-04 were performed.

Table 1. Compositions for the mould powders evaluated in the present work

\begin{tabular}{c|c|c|c|c|c|c}
\hline Mould powder & $\mathbf{C a O}$ & $\mathbf{S i O}_{2}$ & $\mathbf{A l}_{2} \mathbf{O}_{3}$ & $\mathbf{F}$ & $\mathbf{C}_{\text {livre }}$ & $\mathbf{Z r O}_{2}$ \\
\hline ST-SP/BB-04 & 31,3 & 26,0 & 11,9 & 2,7 & 15,0 & - \\
\hline ST-SP/BB-04Z & 30,3 & 24,8 & 12,8 & 2,0 & 14,9 & 1,8 \\
\hline
\end{tabular}

\subsection{Viscosity}

Viscosity measurements were performed using a rotation viscometer TA Instruments VIS 403. Viscosity measurements results can be seen at Figure 1 for the mould powder ST-SP/BB-04 and at Figure 2 for the new one $\mathrm{ZrO}_{2}$-bearing ST-SP/BB-04Z.

As expected [1], break temperature is higher for the $\mathrm{ZrO}_{2}$-bearing mould powder since $\mathrm{ZrO}_{2}$ additions forces up the break temperature: $\mathrm{Tbr}=1225.1^{\circ} \mathrm{C}$ for the ST$\mathrm{SP} / \mathrm{BB}-04$ and $\mathrm{Tbr}=1248.6^{\circ} \mathrm{C}$ for the ST-SP/BB-04Z. Break temperature is related to first crystals formation during cooling; thus, it can be said that the $\mathrm{ZrO}_{2}$-bearing mould powder has higher crystallisation tendency.

Regarding viscosity value for the liquid slag, at $1300^{\circ} \mathrm{C}$ it is lower for the $\mathrm{ZrO}_{2}$-bearing mould powder (21\% lower). Mould powder main function is the creation of a lubricant film at mould/strand interface. It is essential that the mould be lubricated throughout. Failure to do so could lead to a variety of problems, including sticker breakouts $[1,4]$. 


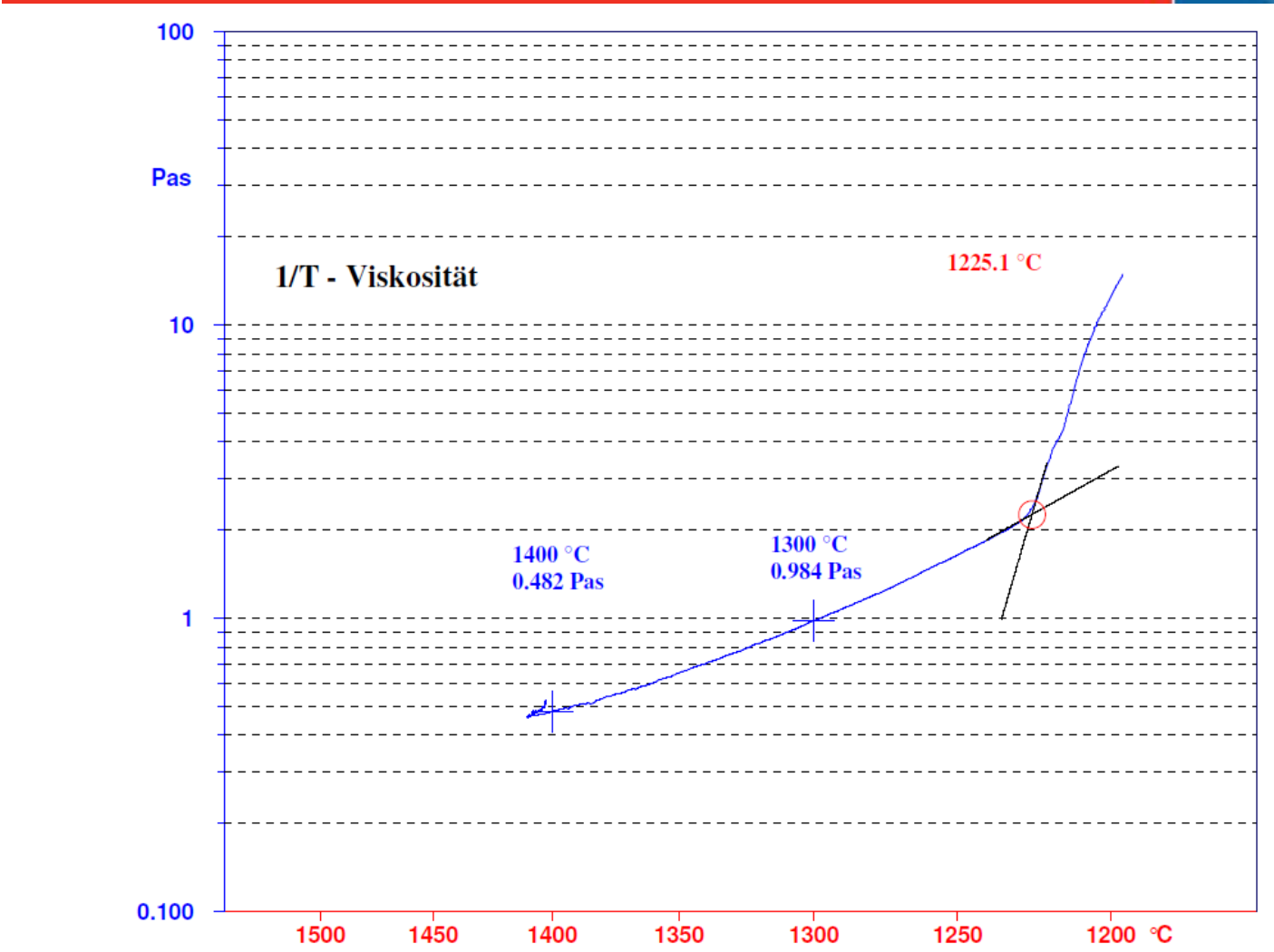

Figure 1. Viscosity measurements taken using a rotation viscometer for the ST-SP/BB-04 (composition at Table 1)

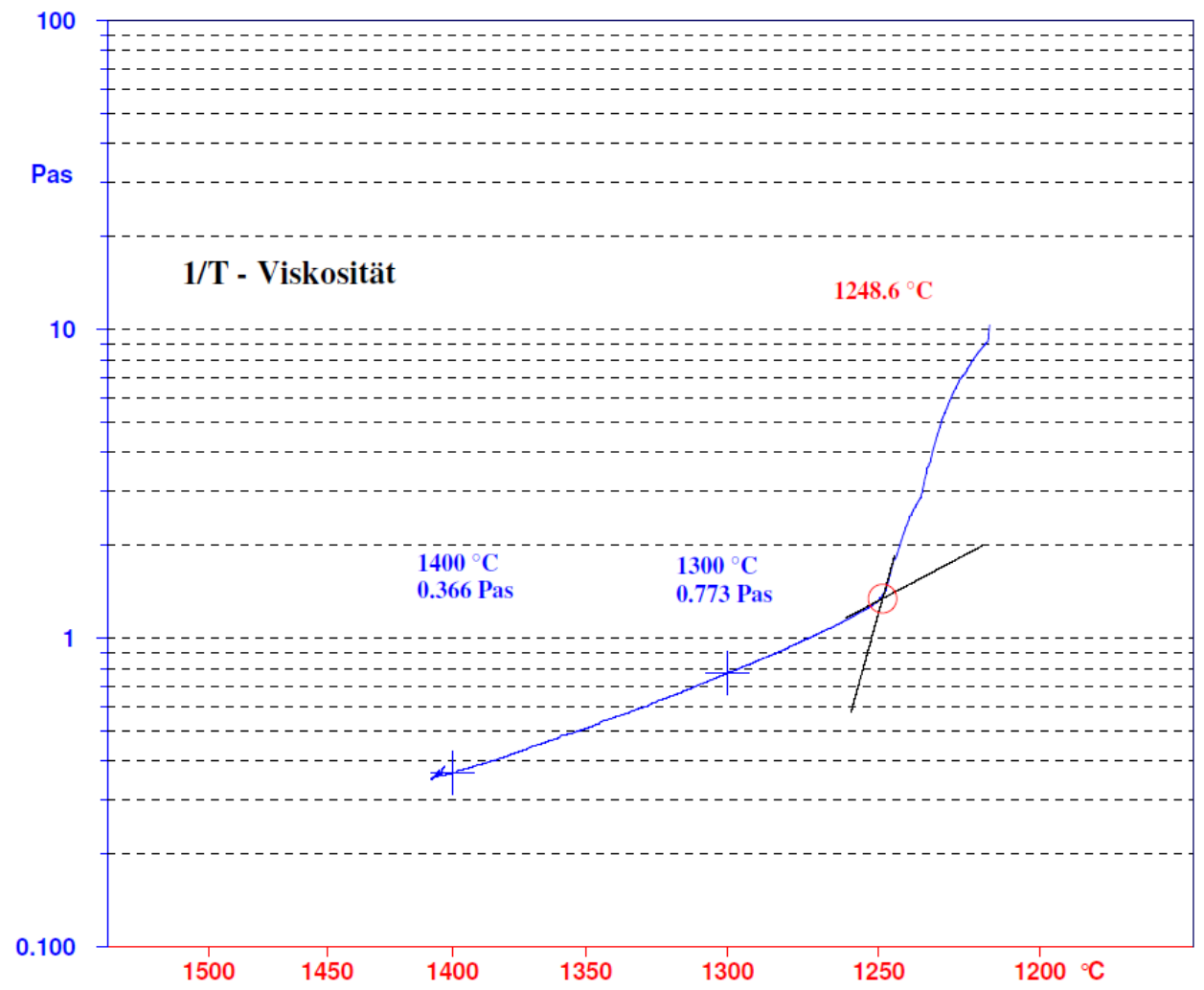

Figure 2. Viscosity measurements taken using a rotation viscometer for the ST-SP/BB-04Z (composition at Table 1)

Additionally, the test herein referred to as Ramp Test was performed. In this test 0.5 $\mathrm{g}$ of sample is put inside an $\mathrm{Al}_{2} \mathrm{O}_{3}$ boat with a fixed slope $\left(15^{\circ}\right)$. The inclined boat with 
the sample on its higher part is heated in a furnace at $1330^{\circ} \mathrm{C}$. The molten slag flows down the boat. The length of the slag ribbon (molten mould powder) along the vessel is measured. Figure 3 shows that slag ribbon length is higher for the $\mathrm{ZrO}_{2}$-bearing mould powder.
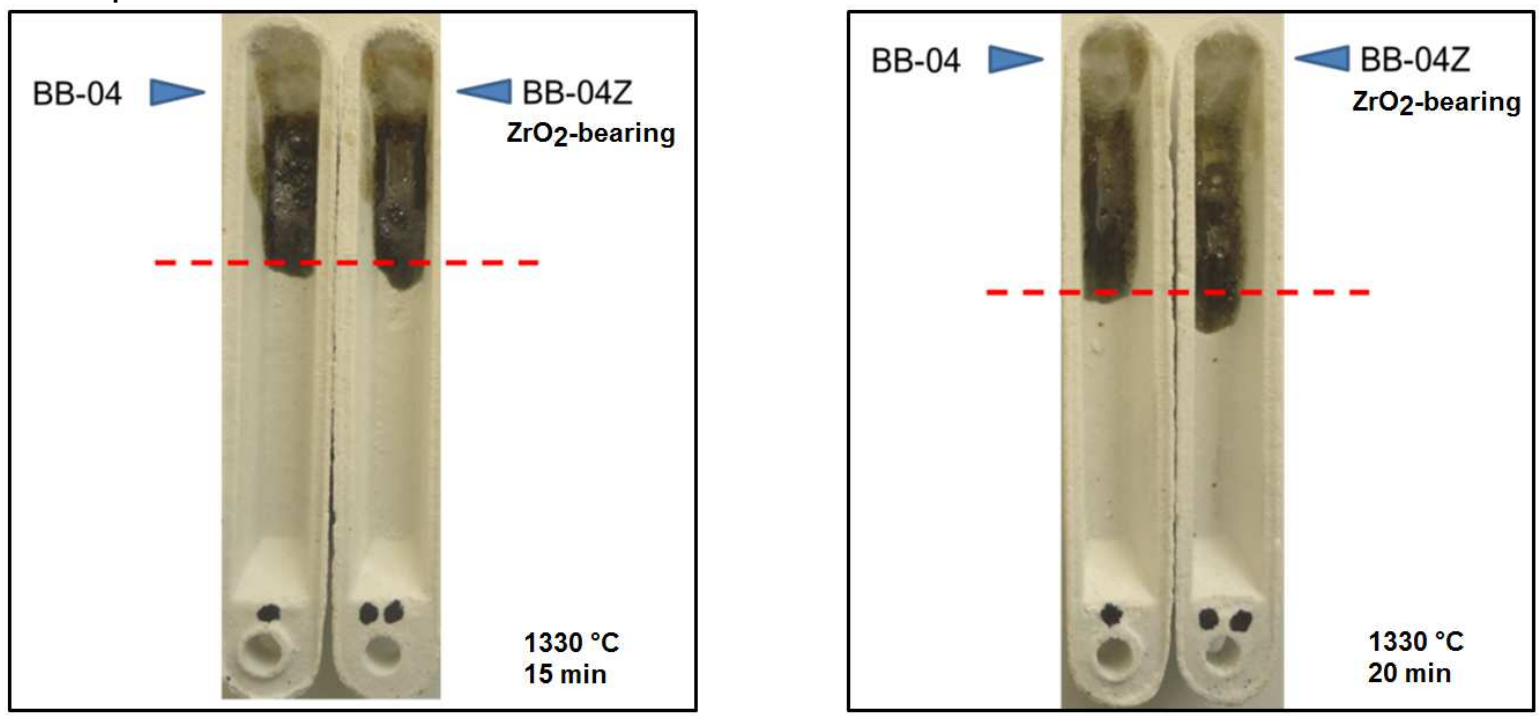

Figure 3. Ramp Test results at $1330^{\circ} \mathrm{C}$ for $15 \mathrm{~min}$ (left) and $20 \mathrm{~min}$ (right).

\subsection{Crystallinity Analysis}

Decarburized sample was put in a platinum crucible and heated at $1300^{\circ} \mathrm{C}$ for 20 min. The mould powder was then poured into a platinum mould at $500^{\circ} \mathrm{C}$ and maintained at this temperature for 20 min for annealing. The samples were cut; results are shown at Figure 4. Original value of the image magnification which was obtained through the optical microscope is $20 x$. The samples were not etched.

A thin crystalline layer can be seen at the bottom (slag/mould interface) for the STSP/BB-04 sample. The $\mathrm{ZrO}_{2}$-bearing sample is $100 \%$ crystalline.

The higher crystallisation tendency for the $\mathrm{ZrO}_{2}$-bearing sample can be explained considering that probably $\mathrm{ZrO}_{2}$ addition promoted crystallisation of cuspidine $\left(3 \mathrm{CaO} .2 \mathrm{SiO}_{2} \cdot \mathrm{CaF}_{2}\right)[1]$.

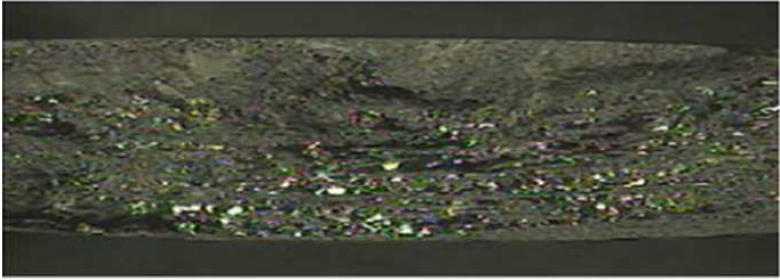

ST-SP/BB-04 0\% ZrO2

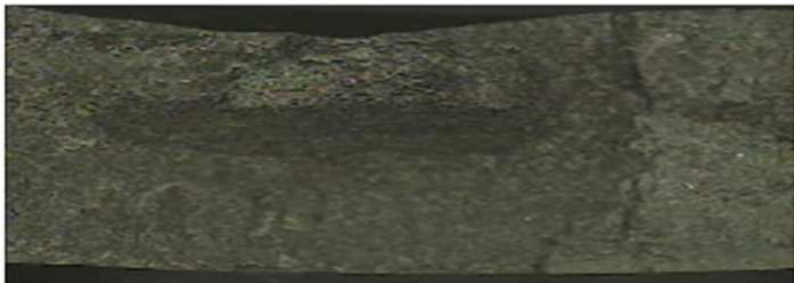

ST-SP/BB-04Z $1.8 \% \mathrm{ZrO} 2$

Figure 4. Crystallinity analysis results for ST-SP/BB-04 (left) and for the new $\mathrm{ZrO}_{2}$-bearing mould powder (right). Annealing was performed at $500^{\circ} \mathrm{C}$ for $20 \mathrm{~min}$, after heating at $1300^{\circ} \mathrm{C}$ for $20 \mathrm{~min}$.

Considering laboratory tests results - break temperature and crystallinity analysis - it can be seen that the $\mathrm{ZrO}_{2}$-bearing mould powder presents different solidification behaviour, i.e., higher tendency for crystallisation. 


\section{INDUSTRIAL TESTS}

The mould powders ST-SP/BB-04 and ST-SP/BB-04Z (compositions at Table 1) were tested at a Brazilian steelworks for beam blank continuous casting. Steel composition can be seen at Table 2, and beam blank gage at Figure 5.

Industrial tests were performed during 12 heats (three sequences). With the 4-strand continuous casting machine, 2 strands were used for the ST-SP/BB-04 and 2 strands were used for the ST-SP/BB-04Z, simultaneously, maintaining the same operational parameters. Casting speed was $0.85-1.0 \mathrm{~m} \mathrm{~min}^{-1}$.

Table 2. Composition of the steel used for the industrial tests [wt\%].

\begin{tabular}{c|c|c|c|c|c|c}
\hline & $\mathbf{C}$ & $\mathbf{M n}$ & $\mathbf{S i}$ & $\mathbf{A l}$ & $\mathbf{N b}$ & $\mathbf{N}$ \\
\hline Min. & 0,14 & 1,1 & 0,15 & - & 0,015 & - \\
\hline Max. & 0,23 & 1,35 & 0,35 & 0,01 & 0,035 & 0,009 \\
\hline
\end{tabular}

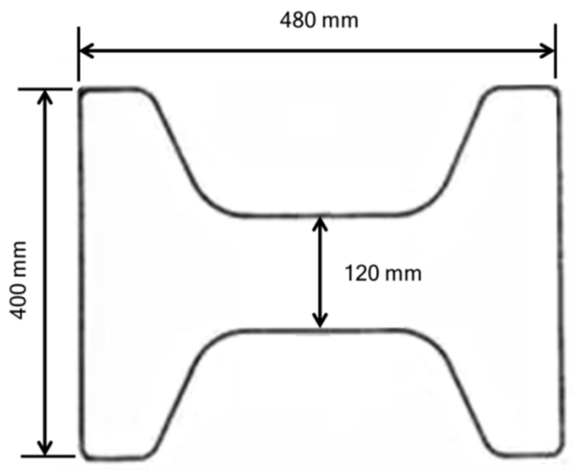

Figure 5. Beam blank gage used for the industrial tests.

\subsection{Heat Transfer Rate Reduction}

Considering the mould of the continuous casting machine, the difference between the water inlet and the water outlet temperature was monitored $(\Delta T)$. Results are summarized at Figure 6 . When using the $\mathrm{ZrO}_{2}$-bearing mould powder heat transfer rate is ca. $10 \%$ lower. That is an important result, considering that reduction of heat transfer rate helps alleviate problems associate with longitudinal cracking that arises from the mismatch in the thermal contraction coefficients of $\delta$-ferrite and austenite [7]. 


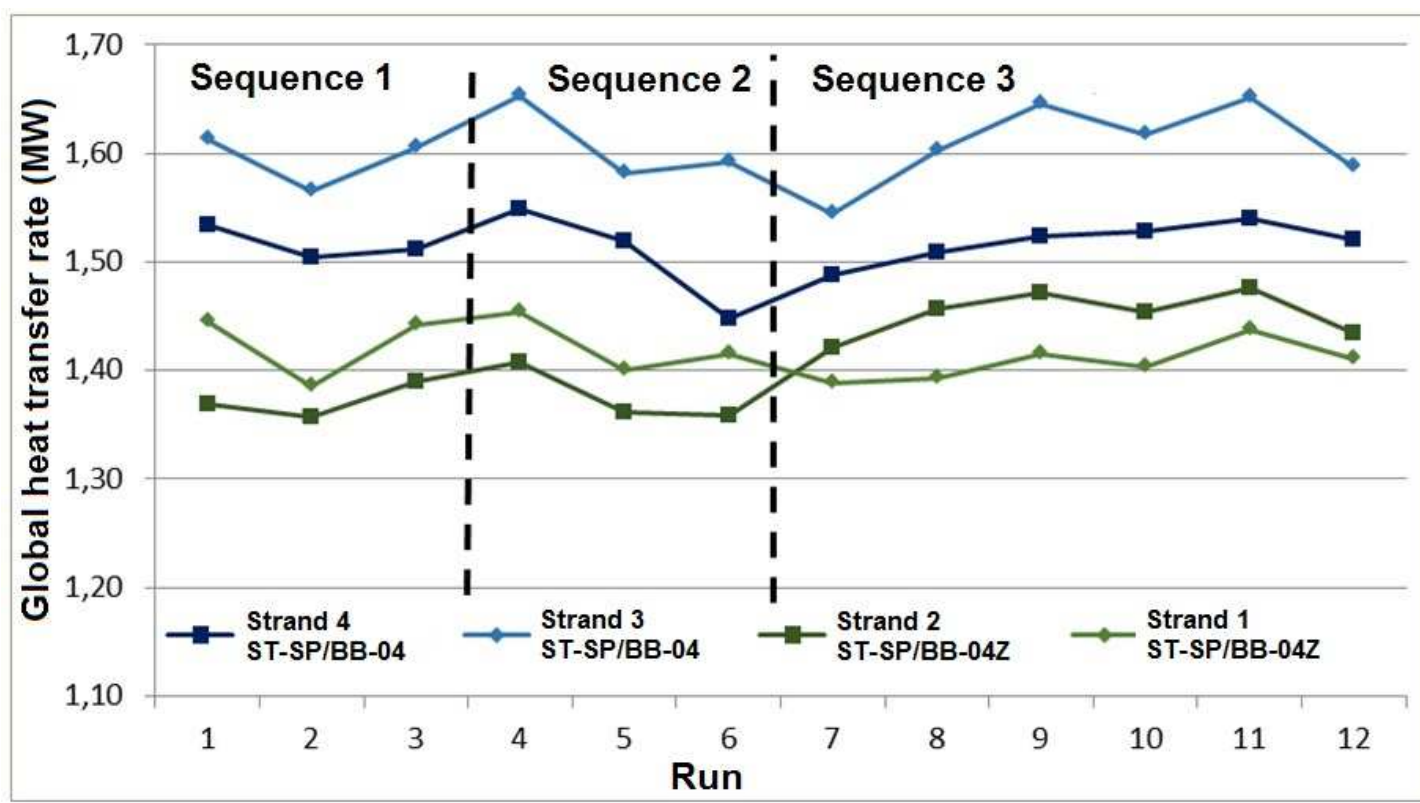

Figure 6. Global heat transfer rate per run for the four strands.

\subsection{SEN erosion rate reduction}

Another benefit when adding $\mathrm{ZrO}_{2}$ in mould powders is to reduce erosion of SENs at the slag/metal interface [1]. The mould powders ST-SP/BB-04 and ST-SP/BB-04Z were used with the same SEN; at Figure 7 this SEN is shown with the regions which suffered erosion. Through measurements it was determined that when using the $\mathrm{ZrO}_{2}$-bearing mould powder erosion rate was ca. 9\% lower. Thus, a significant decrease of the SEN erosion was observed.
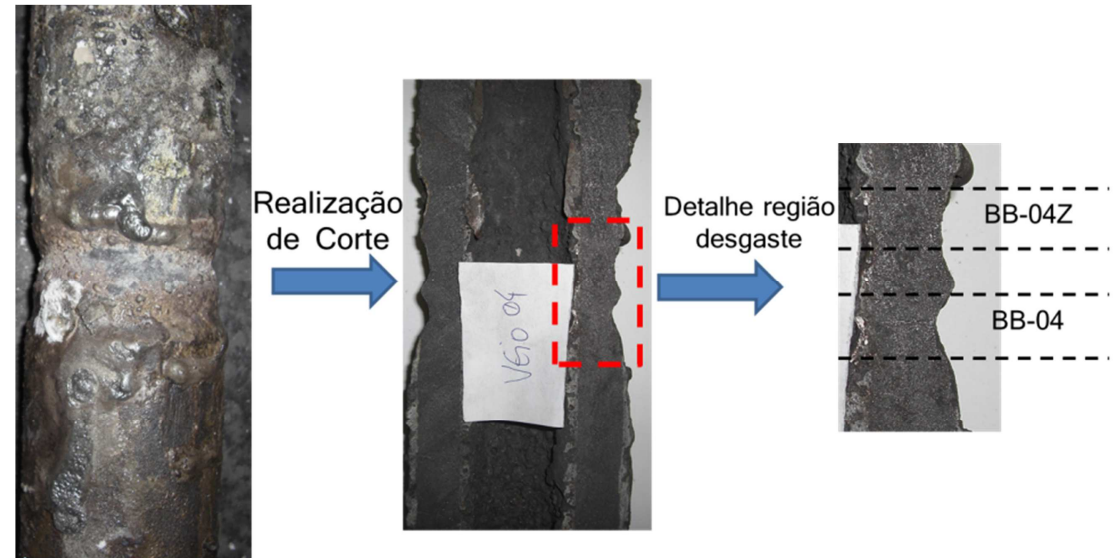

Figure 7. SEN images: (left) SEN after continuous casting; (centre) after cutting the SEN; (right) regions of the SEN for which different mould powders were used.

\section{CONCLUSIONS}

Through laboratory tests and industrials tests the following conclusions can be withdrawn considering the mould powders ST-SP/BB-04 and ST-SP/BB-04Z:

$\checkmark \mathrm{ZrO}_{2}$ addition can reduce horizontal heat transfer rate for the mould during continuous casting of steel, alleviating problems associated with longitudinal cracking

$\checkmark \mathrm{ZrO} 2$ addition reduce erosion of SEN at the slag/metal interface 


\section{REFERENCES}

1 Mills, K.C., The Making, Shaping and Treating of Steel / Casting Volume, Chapter 8: Mold Powders for Continuous Casting. 2003, The AISE Steel Foundation: Pittsburgh.

2 Kromhout, J.A., Mould powders for high speed continuous casting of steel. 2011, Doctoral dissertation, Technische Universiteit Delft.

3 Hooli, P., Study on the layers in the film originating from the casting powder between steel shell and mould and associated phenomena in continuous casting of stainless steel. 2007, PhD dissertation, Helsinki University of Technology.

4 Garcia, A., Spim, J. A., Santos, C. A., Cheung, N., Lingotamento contínuo de aços (Portuguese). 1 ed. 2006, São Paulo: Brazilian Association of Metallurgy, Materials and Mining.

5 Klug, J.L., Crystallisation control for fluorine-free slags using the Single Hot Thermocouple Technique / available in http://www.bibliotecadigital.ufrgs.br/da.php?nrb=000863376\&loc=2012\&l=c2c154f9197e $51 \mathrm{f} 7$ in Fakultät 5 / PPGE3M. 2012, TU Bergakademie Freiberg and Universidade Federal do Rio Grande do Sul (bi-national doctorate): Freiberg (Saxony, Germany) and Porto Alegre (Rio Grande do Sul, Brazil).

6 Klug, J.L., Hagemann, R., Heck, N. C., Vilela, A. C. F., Heller, H. P., Scheller, P. R., Crystallisation control in metallurgical slags using the Single Hot Thermocouple Technique. Steel Research International, 2013. 84(4).

7 Klug, J.L., Hagemann, R., Heck, N. C., Vilela, A. C. F., Heller, H. P., Scheller, P. R., Fluorine-Free Mould Powders for Slab Casting: Crystallization Control in the $\mathrm{CaO} \mathrm{SiO}_{2}$ TiO2 Na2O Al2O3 System. Steel Research International, 2012. 83(12).

8 Nakada, H. and K. Nagata, Crystallization of $\mathrm{CaO}-\mathrm{SiO} 2-\mathrm{TiO} 2$ slag as a candidate for fluorine free mold flux. ISIJ International, 2006. 46(3): p. 441-449.

9 Zhang, Z., G. Wen, and Y. Zhang, Crystallization behavior of F-free mold fluxes. International Journal of Minerals, Metallurgy and Materials, 2011. 18(2, April 2011). 